\title{
B2B E-Marketplaces in the Airline Industry: Process Drivers and Performance Indicators
}

\author{
CLAUDIA MARIA WAGNER*, BERND HUBER, EDWARD SWEENEY, AUSTIN \\ SMYTH
}

National Institute for Transport and Logistics, Dublin, Ireland, Tel. +353 1644 5723, Fax. +3531661 1943,

E-mail: claudia.wagner@nitl.ie; bernd.huber@nitl.ie; edward.sweeey@nitl.ie, austin.smyth@dit.ie

*Corresponding author. Email: claudia.wagner@nitl.ie

\section{Abstract}

Competitive pressures are increasing within and between different strategically oriented groups of airlines. This paper focuses on the level of efficiency improvements gained by using e-Marketplaces in the procurement process. Findings from a survey among 88 international airlines reveal that the use of Business-to-Business (B2B) e-Marketplaces does play different roles across the various airline groupings. Airlines that are involved in strategic alliances show higher joint procurement activities than airlines that are not involved in strategic alliances. However, alliances are probably viewed as loose arrangements and thus airlines may be reluctant to share information on procurement prices and processes with another airline that could also be acting as a competitor. The financial involvement in or initiation of e-Marketplaces by airlines is very low. Low cost airlines show high use of e-Marketplaces, but demonstrate little financial involvement in contrast. Overall, the categories of spares and repairs, office supplies, tools and ground support equipment (GSE) show the greatest potential for reducing costs and increasing procurement 
process efficiencies. The intense competitive pressures facing carriers will make their search for tools to realise even incremental savings and efficiency gains ever more urgent. There is evidence that e-Marketplaces are one tool to improve such performance indicators.

Keywords: Airline Industry, B2B E-Marketplaces, E-Procurement, Competitive Advantage

\section{Introduction}

The airline business is one of the most competitive industries within the economic environment, at least from a regional point of view (Jarach, 2002). Moreover and as a consequence, the airline industry is a particular case in point incorporating as it does distinctive industry features that are linked with continuous change. Evidence of this can be found when considering liberalisation and deregulation issues, privatisation, etc. where those airlines who survived were those who were able to adapt the fastest to certain environmental changes in business terms. Now with the accelerating use of the Internet, the airline industry is forced to move into another stage of corporate evolution. In the 1990s, the use of the Internet as a sales channel for tickets was promoted as highly promising (e.g. Roy and Filiatrault, 1998), but at that time, little academic research was published about the potential of Business-to-Business (B2B) practices over the Internet. In the late 90s, B2B e-

Business became more and more the focus of firms' strategies, while simultaneously a relatively large number of B2B e-Marketplaces emerged. A B2B e-Marketplace exchange is a central marketplace facilitated by information and communication technologies (ICT), in which multiple buyers and suppliers come together to gather information and buy and sell goods and services (Bakos, 1998). 
Christiaanse and Markus (2003) argue that e-Marketplaces have the potential to affect company and supply chain performance and thus alter industry structure. However, eMarketplaces have gained little momentum in industry so far and their failure rate is very high (Gill and Wu, 2001). Due to the lack of revenues they generated many had to cease operations or merge with other industry players. It is predicted that only a few eMarketplaces will survive in each industry by succeeding to reach a critical mass of participants, and the right variety of products and services to cover the needs of the particular industries (Oesterle and Fleisch, 1999). These events, however, have led to the fact that many companies are still very reluctant in using e-Marketplaces in procurement. So far, limited academic research has been undertaken to explore the value creation of B2B e-Marketplace models in the aviation industry. A sound theoretical analysis is necessary to explore whether or not e-Marketplaces have the potential to add value to procurement in the aviation industry. Thus, following this introduction, an overview of developments of the airline industry is outlined and a theoretical background of B2B e-Marketplaces and their specific role in the airline industry is explained in a more detailed manner. Based on those theories, hypotheses are developed and the methodology for their assessment is explained. Finally, the results are discussed and conclusions presented.

\section{Theoretical Background}

\subsection{Developments in the Aviation Industry and ICT}

The airline industry can be characterised as a very unique kind of industry. Bourgeois and Eisenhardt (1988) have described it as a high velocity environment, where there is sharp and discontinuous change in demand, competitors, technology, and regulation, overlapped 
with continuous dynamism or volatility. Furthermore, characteristics of the airline industry include (1) few firms having (2) substantial market share, with (3) differentiated and/or homogeneous products, and (4) high barriers to entry. These traits lean toward an oligopoly market structure (Vo, 2002). The concept of 'national' airlines has played an important strategic role in state affairs and led to tight governmental control, which meant that interorganisational co-operative work between airlines and even particular suppliers was very restrictive. Many airlines are still fully or at least partially government-owned (e.g. Chan, 2000). However, a trend towards globalisation has emerged due to liberalisation and deregulation processes in several parts of the world, leading to various strategies aimed at improving global competitiveness (e.g. Ehmer, 2001; Janic, 1997; Oum, Wit and Yoshida, 2001).

The post-deregulation environments caused a multitude of changes and forced the industry into free privatised markets with severe price competition, where many airlines, especially in the U.S.A., did not survive, or were forced into mergers, consolidations or leveraged buy-outs (e.g. Glisson et al., 1996). Deregulation also brought new business models, such as low cost airlines to operate on point-to-point routes. Low cost airlines have gained cost advantages mainly due to, for example, the use of uncongested and less busy airports (which charge lower costs), very limited in-flight service, short turnaround times on the ground or less personnel in the air and on the ground. Low cost airlines typically use only one type of aircraft in order to have a high degree of crew flexibility, higher aircraft to personnel ratios, fewer stand-by crews and lower maintenance costs.

Due to the recent downturn in the industry (as a result of, for example, overcapacities, terrorist attacks and SARS) and the increased competitive pressures from low cost airlines, 
many traditional scheduled airlines have to cope with new service and cost structures. While airlines in Europe and North America now largely operate in highly competitive markets, the majority of the world’s air routes are still very heavyly regulated (e.g. Nijkamp and Pels, 2002; Button, 1996). Due to the restrictive nature of international competition in the industry, domestic airlines have only a limited means of competing globally. Therefore, while in domestic markets cost competition has become a major factor, in the international sector, competitive advantage is often sought in other ways (see Glisson et al., 1996). One of the most meaningful developments has been the formation of strategic alliances (e.g. Agusdinata and Klein, 2002; Oum, Yu and Zhang, 2001; Suen, 2002) which, beyond the co-ordination of schedules and fares, aim at cost reductions through the possibility of joint procurement opportunities in a strategic network approach. More recently for example, airlines involved in strategic alliances and various other partnerships have studied intensively the potential of such joint procurement possibilities and have taken measures in creating consortia-led e-Marketplaces as mediators for aggregating demand and to facilitate transactions. With the above developments, ICT has become increasingly important in both the B2C (Business-to-Consumer) and B2B strategies to enhance operational efficiency and effectiveness in the airline industry value chain (see Figure 1).

'Insert Figure 1 here’.

However, so far, ICT has revolutionised the airline industry mostly in terms of Business-toConsumer developments. One of the most significant developments has been CRSs (Computer Reservation Systems) (e.g. Pemberton, Stonehouse and Barber, 2001) and 
nowadays global distribution systems (GDSs) and public online booking portals (Duliba, Kauffman and Lucas, 2001). Other methods in B2B such as Electronic Data Interchange (EDI) and Enterprise Purchasing Software Systems that use information technology to reduce inefficiencies in corporate purchasing have limitations preventing their widespread adoption. Due to the expense and complexity of these systems, they are generally unsuitable for all but the largest organisations. Therefore, the fragmentation and complexities of the aviation industry and the current paper-based purchasing processes may create a need for B2B solutions such as e-Marketplaces that bring together buyers and sellers of aviation parts and products.

\subsection{Concept of B2B E-Marketplaces and Determinants of Competitive Advantage}

The concept of B2B e-Marketplaces and their potential value creation capabilities cannot be researched without taking into account the link between the diversity of theories of competitive advantage and ICT as well as the specific industry-related drivers. The concept of e-Business (and its subset e-Commerce) and their potential for creation of value and thus sustained competitive advantage has been the focus of recent research work (e.g. Amit and Zott, 2001; Lee, Cho and Lee, 2002). However, academic literature to date has outlined the central issues of e-Business to a limited extent and so far no unified theoretical model has been developed which captures the unique features of this phenomenon (Amit and Zott, 2001). Furthermore, most of this research has focused on businesses and transactions in terms of B2C. In terms of B2B, ICT has been increasingly researched in recent years as the basis for inter-organisational information systems (IOS) that enable firms to transcend organisational boundaries, facilitate the flow of information, and manage linkages between suppliers and customers in the supply chain. E-Marketplaces have evolved from IOS 
(Reimer, 1996). The evolution of virtual B2B e-Marketplaces, created by Internet-based ICT, is an innovation that spans firm and industry boundaries while creating value through new exchange mechanisms, unique transaction methods, and new forms of collaboration between firms (Büchel and Raub, 2002; Van Tulder and Mol, 2002). Yet, the value creation potential of e-Marketplaces in the airline industry and their role in enhancing competitive advantage has not been the focus of academic research to date.

Several theories of competitive advantage provide potentially useful frameworks for the analysis of B2B e-Marketplaces in the aviation industry. The resource-based view has become a popular perspective for explaining sustainable competitive advantage in ICT and e-Business (e.g. Barney, Fuerst and Mata, 1995; Clemons, 1991). Resource-based theory has also been suggested as a meaningful theoretical framework for pursuing competitive advantage through the development of IOS in value chain activities because of the required diffusion of new technology assets (e.g. Kumar and Crook, 1999). However, resource theory as it relates to using ICT to establish a sustainable competitive advantage has been equivocal. In fact, except for ICT managerial skills, Barney, Fuerst and Mata (1995) concluded that ICT can not be a source of sustainable competitive advantage. Because ICT resources are mobile and imitable, firms can only expect to have a temporary competitive advantage, and should view ICT as necessary in maintaining competitive parity (Rasheed and Geiger, 2003).

In determining the value creation of e-Business, Amit and Zott (2001) observed that new value can only be created by the way in which transactions are enabled. In brief, these authors developed a model of the sources of value creation in which the value creation potential depends on four interdependent dimensions: efficiency, complementarities, lock- 
in, and novelty. Clemons (1986) identified the ‘create-capture-keep’ paradigm by focusing on ICT-based customer switching costs as a potential source of competitive advantage. Another theory that describes sources of value creation and thus the achievement of competitive advantage is the transaction cost theory (Christiaanse and Markus, 2003; Williamson, 1983). The strategic network theory expands transaction cost theory to explain the emergence of long-term relationships between firms in terms of the reduced transaction costs enabled by network collaboration (e.g. Jarillo, 1988; Miles and Snow, 1984). A combination of the presented theories is required to situate the value creation potential of eMarketplaces to e-Procurement in literature.

In particular, B2B e-Marketplaces have the potential to positively impact the performance of supply chains by more efficient and frictionless procurement practices, e.g. lower purchase costs, reduced inventory, enhanced efficiency of logistics, as well as increased sales and lower marketing costs (Baron et al., 2000). Since supply chain management encompasses the co-ordination of order generation, order taking, and order fulfilment and distribution of products, services and information (Kalakota and Whinston, 1997), B2B eMarketplaces have the potential to act as mediators for aggregating supply and demand. Weller (2000) notes that the types of e-Marketplaces that develop in a given industry will depend on the complexity and frequency of transactions, the extent of industry concentration and the relative power of buyers and suppliers.

Companies involved in e-Marketplaces can be studied from both the seller's and buyer's point of view. This research investigates the latter. From the purchasing company's point of view, B2B electronic commerce can facilitate procurement innovations to result in reduced purchasing price, reduced cycle time, and improved supplier sourcing (Turban et al., 2000). 
However, so far, most research on B2B e-Marketplaces has focused on analysing operational benefits, rather than addressing the factors that may impact airlines to source electronically. Field applications, technical aspects and financial / revenue models of eMarketplaces have been discussed to a significant extent (Joo and Kim, 2004). However, limited research has been conducted to examine and understand the factors and drivers that are related to e-Marketplace adoption and performance indicators in the airline industry.

\section{Research Design}

\subsection{Research Objectives}

With $\mathrm{B} 2 \mathrm{~B}$, both the online penetration and the value retained by the airlines are expected to be at least twice the level realised by developments in B2C (Airline Business, 2000). However, which types of airlines are taking advantage of this value proposition and have implemented B2B e-Marketplaces? What are the major e-Marketplace adoption enablers and process drivers for airlines? What is the effect on airline performance indicators? A set of hypotheses that are explained in more detail below assess these research questions and were integrated in a survey instrument for airlines.

\subsubsection{Development of Hypotheses}

Environmental Context \& Firm Size. According to Joo and Kim (2004), competitive pressure from the external environment refers to the level of e-Marketplace capability of the firm's industry and, more importantly, capability of its competitors. Kimberly and Evanisko (1981) have found a positive relationship between competition and innovation 
adoption. As more competitors become e-Marketplace capable firms, they may be more inclined to adopt an e-Marketplace in order to maintain their own competitive position.

H1a: External competitive pressure is positively related to e-Marketplace adoption of airlines.

This hypothesis is tested by an analysis of variance using a six-item scale with a Cronbach’s alpha of 0.78 .

Moreover, strategic group types in industries can be identified based on similarities in firm scale, technology, customers served, or products and services in terms of price, features, quality, among other dimensions (Gulati, Nohria, and Zaheer, 2000). Typically, strategic group boundaries are difficult for firms to traverse due to mobility barriers and have been used to explain differential firm behaviour and performance within industries (e.g. Cool and Schendel, 1988). After several waves of deregulation, it is possible to observe generic airline strategies and groupings, i.e. full service airlines, charter airlines, regional airlines and low cost airlines. As such, it is important to explore which types of airlines and which sizes of airlines have adopted e-Marketplaces, thereby strongly contributing to a theory generation process of scope and scale of aviation e-Marketplace use.

H1b: The use of e-Marketplaces is highly dependent on an airline's strategic classification.

This hypothesis is tested by a chi-square test using a four-item multiple choice question.

H1c: The use of B2B e-Marketplaces is related to firm and fleet size. This hypothesis is tested by an analysis of variance using three numeric variables. 
Technological Context. The most basic considerations in new technology adoption are costs to transition to new technology and advantages (or benefits) materialisation from the new technology introduction; the greater the advantage is perceived compared to the current method, the greater the probability that an organisation will adopt the new technology. This perception, in the context of e-Marketplace adoption, can be operationalised as a relative advantage factor (Joo and Kim, 2004). Relative advantage is not the same as awareness. While awareness is mainly concerned with the reception of information about e-Marketplaces, relative advantage captures the extent of agreement with the claimed benefits relative to the adopter's local conditions. While awareness is a precondition of forming a belief, it is the latter that drives an adoption decision. Therefore, it is worth exploring whether or not the overall ICT sophistication of an airline and the number of Internet services used (e.g. online request for quotations, search for new suppliers) impact its e-Marketplace adoption decision.

H2a: E-Marketplace implementation is positively related to an airline's overall ICT sophistication.

This hypothesis is tested by an analysis of variance using a four-item scale with a Cronbach’s alpha of 0.92 .

H2b: The adoption of e-Marketplaces among airlines is positively related to the overall number of Internet services used.

This hypothesis is tested by an analysis of variance using a three-item scale. Cronbach's alpha is not applicable for this formative scale.

Joint Procurement and Buying Power. A consolidated customer base for a specific product can increase collective buying power. The airline industry was one of the first 
industries to adopt the concept of strategic alliances. Oum, Park and Zhang (2000) define 11 areas of joint or co-ordinated activities, including joint-maintenance and joint procurement of fuel or other supplies. Jarach (2002) argues that sophisticated eProcurement applications can generate competitive improvements for firms because of the sharing of information and the planning of joint activities. E-Marketplaces can be viewed as a tool to facilitate collaborative supply networks (Christiaanse and Kumar, 2000).

H3a: Airlines involved in alliances or other sorts of partnerships use B2B eMarketplaces more than airlines that are not involved in alliances or other sorts of partnerships.

This hypothesis is tested by an analysis of variance using a five-item scale. Cronbach's alpha is not applicable for this formative scale.

H3b: The extent of resource and information sharing is positively related to eMarketplace adoption among airlines.

This hypothesis is tested by an analysis of variance using an eight-item scale with a Cronbach's alpha of 0.85 .

H3c: Airlines involved in e-Marketplaces have a higher integration level of joint procurement than airlines that are not.

This hypothesis is tested by an analysis of variance using a nine-item scale. Cronbach's alpha is not applicable for this formative scale. 
Outsourcing. At the strategic level, more and more companies aim to focus on their core competencies in order to lower costs and achieve competitive advantage. In the airline industry, productivity is considerably influenced by the extent to which a carrier outsources its activities and by the nature of the product it offers to its customers.

H4a: The extent of outsourcing is dependent on an airline's strategic orientation.

This hypothesis is tested by an analysis of variance using an eight-item scale. Cronbach's alpha is not applicable for this formative scale.

H4b: The extent of outsourcing is positively related to the adoption of e-Marketplaces among airlines.

This hypothesis is tested by an analysis of variance using an eight-item scale. Cronbach's alpha is not applicable for this formative scale.

Organisational Procurement Context. Two key areas of procurement strategy are risk reduction and cost reduction. In a centralised approach, decisions are taken at the most senior or central level of a purchasing organisation, while in a decentralised approach, decisions are taken at a lower and more distributed level. Purchasing organisations can also be decentralised, but centrally co-ordinated. In such a case decisions are taken both at senior and lower levels, either separately or in an integrated manner. A further goal is to select and manage a supply base capable of providing performance advantages in product cost, quality, technology, delivery, or new product development. Therefore, it is worth investigating:

H5a: E-Marketplace implementation is dependent on an airline's procurement organisation strategy. 
This hypothesis is tested by an analysis of variance using a three-item multiple choice question.

H5b: The adoption of e-Marketplaces is positively related to a decrease in the number of suppliers.

This hypothesis is tested by an analysis of variance using a two-item scale. Cronbach's alpha not applicable for this formative scale.

Performance Indicators. The worldwide market for aviation parts and products is highly fragmented and includes a variety of organisations and suppliers, including airlines, OEMs, distributors, fixed base operators or traders and brokers. Buyers may spend a significant amount of time using conventional media to identify and complete procurement processes. Given the sporadic nature of demand for aircraft maintenance parts, airline operators also perceive difficulties in parts demand forecasting (e.g. Clarke, 1998). Airlines often face very high costs in locating spare parts and components, especially for older aircraft types and aircraft on ground (AOG) situations. Further, aircraft availability has to be maximised at peaks and maintenance fitted into times when the planes are not required for commercial activities. In many cases, airlines do hold more inventory than required to avoid for instance AOG situations or because parts become obsolete with changes in the fleet type. Also many parts have a limited shelf life. It can therefore be hypothesised that B2B eMarketplace adoption offers the prospect of a wide range of benefits. In particular, the emergence of B2B e-Marketplaces has the potential to add value to procurement by disintermediation, reduction of search costs and time efficiency enhancements, increased transparency of the supplier base, or reductions in inventory or product purchasing prices. 
H6a: B2B e-Marketplace adoption is positively related to the overall performance and satisfaction with the procurement practices of an airline.

This hypothesis is tested by an analysis of variance using a seven-item scale with a Cronbach's alpha of 0.87 .

H6b: The use of e-Marketplaces has a positive effect in terms of reducing of purchase order costs of an airline.

This hypothesis is tested by an analysis of variance using one numeric variable.

Little is known about successful approaches in B2B e-commerce on the net (Timmers, 1999). Bagchi and Watson (2002) indicate that characteristics of e-Marketplaces that affect the generation of revenue are the number of members, transaction volume, number of product types, scope for expansion into related industries, scope for vertical integration, and the number of Web site page views. The revenue models of e-Marketplaces represent the investment costs for airlines. These cost channels can include license fees, professional service fees, transaction fees, advertising fees, payment for supply chain savings, and subscription or membership fees. Some costs are based on some combination of these channels. E-Marketplace implementation can produce value in different ways, some tangible and others intangible. To realise value from e-Marketplace procurement, the intangibles and soft factors such as enhanced decision making capabilities and improved buyer-seller contacts must be considered as well (National Electronic Commerce Coordinating Council, 2002). Therefore, whether or not the use of e-Marketplace has any positive effect on the overall airline performance (e.g. increase in passenger numbers, turnover) should be investigated. 
H7a: A reduction in purchasing process costs and in procurement product prices can exceed the investment costs for the use of e-Marketplaces.

This hypothesis is tested by a chi-square test using a one item-scale.

H7b: The use of B2B e-Marketplaces is positively related to an airline's overall business performance.

This hypothesis is tested by an analysis of variance using a four-item scale with a Cronbach’s alpha of 0.87 .

\subsection{Data Collection}

The data collection was carried out in the form of an in-depth questionnaire survey addressing senior procurement personnel at airlines around the globe. Survey pilot testing was done by administering the questionnaire to industry practitioners and academics with experience in this field of research. Feedback from the pilot testing was used in refining the questionnaire. Questionnaires have been sent in successive follow-ups to a sample of 300 senior purchasing staff of international passenger airlines of different types and sizes. Stratified random sampling was employed, based on the airline size of the entire passenger airline population which constitutes, according to Flight International (2004), approximately 1200 airlines. The world air transport market is very concentrated and half of the world's fleet is operated by just the 17 large airlines (Airlines Gate, 2001). Almost $70 \%$ of world airline revenue is generated by just 100 airlines (Sahi, 2004). According to Flight International (2003), the world airline industry consists of 65\% of airlines with 10 aircraft or less, $17 \%$ with a fleet of $11-20$ aircraft, $13 \%$ with a fleet of $21-50$ aircraft, and just $5 \%$ with a fleet over 51 aircraft. Strata were developed to ensure that all participating airlines are adequately represented in the target sample. Therefore, the target sample was 
divided into four sectors based on airline fleet size (from 1-10; 10-20; 20-50; 50 and more). Out of each size group, 75 airlines were selected randomly. 88 responses were received representing a response rate of $29.3 \%$. The following distribution occurred in the sample: less than 10 aircraft (18\%), from 10 to 20 aircraft (23\%), from 21 to 50 aircraft (29\%), 51 or more aircraft (30\%).

Full service and regional airlines are projected to have a 60\% total airline market share in comparison to $15 \%$ for charter airlines and $25 \%$ for low cost airlines within the next five years (Schneiderbauer and Fainsilber, 2002). In the sample the following strategy distribution occurred: regional airlines (12\%), full service airlines (44\%), charter airlines (22\%) and low cost airlines (22\%). The sample can, therefore, be considered as broadly representative of the population. The early and late respondents have also been tested for statistically significant differences and non-response bias with regard to airline size and classification as well as use of e-Procurement systems and e-Marketplace portals. Results of the t-tests show that there are no significant differences between early and late respondents. 


\section{Discussion of Key Findings}

The contingency model in Figure 2 illustrates the results from the airline survey. 'Insert Figure 2 here'.

Environmental Context \& Firm Size. The survey data verify that regional, scheduled and charter airline groups experience highly competitive pressures to reduce their cost levels. Interestingly, low cost airlines tend to report lower competitive pressures from the business context $(\mathrm{p}=<0.1 \%, \mathrm{~F}=15.71)$. Low cost airlines report a slight increase in passenger numbers and overall profits, while regional scheduled and charter airlines are tending to experience an overall decline in performance. These results might be attributable to the continued rise in the number of new-entrant low cost airlines, the after-effects of overcapacities in the 1990s as well as additional costs incurred due to increased terrorist threats. It has further been investigated whether or not increased competitive pressures are related to an increased e-Marketplace adoption. However, results reveal that there is not a significant relationship (Hypothesis H1a: $\mathrm{p}=85.1 \%, \mathrm{~F}=0.02$ ). The decision to implement an e-Marketplace might not be completely attributable to the current environmental situation, but rather be seen as a long-term investment and a means of facilitating procurement as well as reducing procurement related costs. Besides economic and financial benefits, Lenz, Zimmermann and Heitmann (2002) confirm that soft aspects like partnership and the use of extended services come more and more into attention when making the decision to use an e-Marketplace.

Use of a B2B e-Marketplace can be determined by either financial participation in terms of ownership and/or by the use of this means in the procurement of different commodities. The survey results indicate that $25 \%$ of survey respondents are involved financially in an e- 
Marketplace, with scheduled airlines showing the highest penetration at $68 \%$, followed by low cost airlines with $23 \%$. Overall, $65 \%$ of airlines report using e-Marketplaces for procurement operations. Again, in the group of full service airlines, e-Marketplace adoption is the highest with $82 \%$, followed by low cost airlines with $79 \%$, regional airlines with $50 \%$ and finally charter airlines with $27 \%$ (Hypothesis H1b: highly significant with $\mathrm{p}=<0.1 \%$; chi2=19.73). Low cost airlines show a low financial involvement in terms of ownership, but high adoption rates. This might be due to the fact the low cost airlines avoid all unnecessary risks, try to be as flexible as possible and tend to outsource everything except their core business activities. Charter airlines show the least interest in using an eMarketplace. This might be due to the fact that a large proportion of them are vertically integrated in tourism companies that dictate decisions in strategic procurement and might not see their charter affiliates as their core business as seats are mostly filled with their own package holiday passengers. Thus, the need to reduce costs and facilitate processes might not be that apparent.

The use of e-Marketplaces clearly increases with the total number of an airline's employees (Hypothesis H1c: $\mathrm{p}=<0.2 \%$; $\mathrm{F}=10.3$ ), the number of employees in purchasing (Hypothesis H1c: $\mathrm{p}=<0.1 \% ; \mathrm{F}=14.4$ ) and the fleet size (Hypothesis H1c: $\mathrm{p}=<0.9 \% ; \mathrm{F}=7.2$ ). According to Lehmann (1985), the size of a firm can influence its level of innovation. Palvia and Chervany (1995) argue that larger firms are more willing and capable of taking the risk of adopting new technologies. Hadaya (2004) confirms that a firm's size is positively related to its level of use of B2B e-Marketplaces.

Technological Context. A significant relationship between e-Marketplace implementation and an airline's overall ICT sophistication was found (Hypothesis H2a: $\mathrm{p}=3.5 \%$; $\mathrm{F}=4.51$ ). 
There was also a very significant dependence between the adoption of e-Marketplaces and the number of Internet services used (Hypothesis H2b: $p=0.26 \%$; $F=9.75$ ). Hence, the survey confirmed technology competence as an e-Marketplace adoption driver for airlines. The findings coincide with the view of Barratt and Rosdahl (2001), who regard the use of customised services as a key area of technology competence.

Joint Procurement and Buying Power. The survey results also suggest that airlines involved in strategic alliances or other partnerships tend to exhibit greater levels of use of B2B e-Marketplaces (Hypothesis H3a: p=3.7\%; F=4.37). Jarach (2002) argues that sophisticated e-Procurement applications can generate competitive improvements for firms because of the sharing of information and the planning of joint activities. Strategic alliances have become increasingly important elements in a firm's portfolio of strategies and are viewed as a source of competitive advantage in the airline industry (Suen, 2002). However, surprisingly, the extent of resource and information sharing is not related to e-Marketplace adoption (Hypothesis H3b: $\mathrm{p}=80.2 \%$; $\mathrm{F}=0.05$ ). Apparently, the involvement in strategic alliances and e-Marketplaces alone does not necessarily lead to a higher level of resource and information sharing.

Moreover, airlines involved in e-Marketplaces do not take advantage of joint procurement tools to a greater extent than non-adopters of e-Marketplaces (Hypothesis H3c: $\mathrm{p}=75.3 \%$; $\mathrm{F}=0.10$ ). Academic research focused on economies of scale among airlines and a major conclusion was that above a certain, very low level, economies of scale do not exist to a significant extent (e.g. Caves, Christensen, Tretheway, 1984; Crane, 1944; White, 1979; Xu and Windle, 1994). For low cost items and those with a high rate of consumption, such as aircraft fuel and in-flight catering supplies, the level of product price reductions available to 
a group of airlines would be similar to that available to individual airlines. This is because the demand from individual airlines would be significant for capacity in the supply chain, allowing little room for further discounts for larger customers. However, substantial discounts may be available for large orders of high cost items such as aircraft and maintenance spares and components. The holding of aircraft spares can significantly increase an airline's cost level, not only through the initial purchasing process but also through administration charges and storage costs. When optimising the process of procuring a part, as well as administration and storage, savings could be made through the more efficient use of resources. While an e-Marketplace can be seen as an intermediary for realising those joint-purchasing benefits by enabling aggregate buying (Christiaanse and Kumar, 2000), the awareness and adoption for electronic joint purchasing is still rather low among airlines and not well integrated.

Outsourcing. Outsourcing is predominantly employed in maintenance related areas. The level of outsourcing is highly dependent on an airline's strategic orientation (Hypothesis H4a: $\mathrm{p}=<0.1 \%$; $=6.11)$. Low cost airlines show a much higher extent of outsourcing $\left(\mathrm{X}_{\mathrm{LC}}=\right.$ 3.17) than their full service $\left(X_{F S}=2.31\right)$, charter $\left(X_{C}=2.18\right)$ and regional airlines $\left(X_{R}=2.54\right)$ counterparts $^{1}$. In most of the cases, in order to minimise their own labour costs and focus on the core business, low cost airlines have outsourced the maintenance of their aircraft and with it, the procurement of respective materials. A.T. Kearney (2004) has published a report on current maintenance, repair and overhaul (MRO) activities, which states that since airlines are trying to lower costs and gain operational cash which is bound in a huge amount of spare parts, many have abandoned their in-house MRO capabilities and facilities. Since

\footnotetext{
${ }^{1}$ All means in this paper are based on a scale from $1=$ not at all to $5=$ totally.
} 
2001, the outsourcing of MRO services has increased by about $10 \%$. Airlines with a high number and diverse kind of fleet may not fully benefit from outsourcing. For example, an airline would require short turnaround times, while this would mean a higher utilisation of staff and higher costs for a provider. The survey data suggests no significant dependence between the extent of outsourcing and the adoption of e-Marketplaces (Hypothesis H4b: $\mathrm{p}=70.7 \%$; $\mathrm{F}=0.14)$. Outsourcing cannot be regarded as a process driver or as a side-effect of e-Marketplace adoption.

Organisational Procurement Context. The adoption of e-Marketplaces may enable airlines to organise their procurement organisation into decentralised operating units, which can be centrally co-ordinated, in order to take advantage of the benefits from both approaches. However, it could not be established that e-Marketplace implementation is dependent on an airline's procurement organisation strategy. No significant differences can be found in terms of centralisation (Hypothesis H5a: $\mathrm{p}=41.7 \%$; $\mathrm{F}=0.68$ ) or decentralisation (Hypothesis H5a: $\mathrm{p}=42.3 \%$; $\mathrm{F}=0.66$ ). In the sample, $45 \%$ operated a centralised purchasing operation, followed by a decentralised but centrally co-ordinated approach (38\%). Only 17\% operated in a decentralised purchasing environment.

Further, the adoption of e-Marketplaces is not related to a decrease $(\mathrm{p}=86.0 \% ; \mathrm{F}=0.02)$ or increase (Hypothesis H5b: $\mathrm{p}=82.1 \%$; $\mathrm{F}=0.04$ ) in the number of suppliers. To ensure the quality necessary and required by many aviation authorities, the aviation and aerospace industry differs from other business sectors, as there are very high barriers to entry due to certification requirements for airlines and suppliers. Products are typically manufactured in low volume with unique design modification and option configurations. High value products are mostly sold under a requirement for full life support with in-service 
modifications and upgrades and vendors almost invariably supply initial maintenance packages including both spares and support. At the top of the value chain the industry has become highly consolidated with almost no competition (Chan, 2000). Thus, airlines are unlikely to decrease or increase the number of suppliers in any high value product groups.

Performance Indicators. Overall, B2B e-Marketplace adoption is positively related to the overall satisfaction and performance of an airline’s procurement management and practices (Hypothesis H6a: p=0.7\%; F=7.58). For example, e-Marketplaces can reduce search costs. Office supplies and spares and repairs are areas with the greatest potential for saving search costs, followed by tools and ground support equipment (see Figure 3).

'Insert Figure 3 here’.

Materials, spares and repairs represent the most frequent commodities to be procured via eMarketplaces while fuel tends to be purchased to a much lesser extent using such platforms. Use of e-Marketplaces to facilitate order processes, overall efficiency enhancement and a greater degree of transparency of suppliers is reported for office supplies, followed by the categories of spares and repairs, interiors and tools/GSE. Analysis reveals that survey participants see B2B e-Marketplaces as a tool to reduce their inventories in certain categories (e.g. spares and repairs). These inventory reductions have increased the reliance of airlines on suppliers of new, used and overhauled parts and products. This is also true for office supplies and tools/GSE. A limited potential for product price reductions by the use of e-Marketplaces was found for fuel, maintenance services and powerplants.

The survey data confirms that the use of e-Marketplaces has a positive effect on the reduction of purchase order cost (Hypothesis H6b: $p=4.8 \%$; $=4.0$ ). Jarach (2002) confirms that a web interface can generate two types of advantage: (1) greater effectiveness 
due to the possibility of shorter buyer search times and due to the possibility of reducing supplier response times, thus simplifying the planning stage of the airline offer; (2) greater efficiency, as B2B online negotiations also allow other actors, that are not part of the usual supplier network to participate in the process with a product or service offer, thus resulting in economies of variety and considerable savings in management. Most respondents further indicated that the achieved reduction in purchasing process costs and product prices exceed the investment costs for the implementation and use of an e-Marketplace (Hypothesis H7a: Chi2=21.21, $\mathrm{p}=0.03 \%$ ), and that those savings achieved occur slightly more in processing rather than product costs. Intangible benefits include the ability to improve and introduce commodity and vendor management, reduce turnaround times, enhance visibility of price changes, and improve spending controls and employee compliance.

Given these benefits from e-Marketplace adoption, the use of e-Marketplaces, however, is not positively related to an airline’s overall performance (Hypothesis 7b: $\mathrm{p}=66.2 \%$; $\mathrm{F}=0.20$ ). While it could be confirmed that e-Marketplace adoption can be advantageous in terms of performance indicators in procurement, a direct link to the overall airline performance (e.g. increase in passenger numbers, profit) could not be established. However, a positive relationship could be identified between the ICT sophistication within an airline organisation and the overall airline performance. Overall airline performance is dependent on a variety of other business and strategy factors (e.g. unexpected environmental factors such as terrorist attacks or health risks such as SARS). 


\section{Conclusions and Future Research Requirements}

There are significant deviations in some areas in terms of e-Marketplace use and perceptions within the different airline groupings. The survey findings reflect the volatility in both the airline industry and the global economy. Competitive pressures are increasing within and between different strategically oriented groups of airlines. Full service and charter airlines in particular experience increased pressures to reduce their cost base, which might be due to the increasing presence of low cost airlines in their respective target markets and the unstable economic environment they are operating in at this particular point of time. Full service and low cost airlines have taken the lead in using eMarketplaces. Adoption of e-Marketplaces is also highly dependent on the airline size, which confirms previous research that larger firms are less subject to knowledge and technology barriers. Further, airlines that are involved in strategic partnerships and alliances and that are sophisticated in the use of ICT systems such as the Internet, are more likely to implement e-Marketplaces, while the airline procurement organisation as well as the extent of joint purchasing and outsourcing does not affect e-Marketplace adoption.

Results have also revealed that e-Marketplace use is positively related to the overall satisfaction with and performance of an airline's procurement practices. Results suggest that e-Marketplaces do reduce search cost of airlines, mostly in the area of spares and repairs, tools/GSE and office supplies. Other benefits typically occur in the facilitation of order processes, a higher transparency of suppliers, reduced inventories, product price reductions and a reduction in purchase order costs. Commodities where markets are fragmented to a higher extent, such as spares and repairs, tools/GSE or office supplies, are traded on e-Marketplaces to a higher extent than commodities with a rather concentrated 
supply base, such as powerplants and accessories, as often the latter items are under full service contracts and complex repair procedures are required.

This paper presented drivers for e-Marketplace adoption in the procurement process of airlines and the achieved performance as a result of adoption. Further research could also seek to investigate e-Marketplace features, such as dynamic pricing models, value added services or start up costs and returns. For example, Raisch (2001) argues that eMarketplaces are currently evolving from simple matching services to offer value-added services that support transactions. A further step in the development will be the integration of knowledge services into transaction exchange, thereby building value trust networks that enhance collaboration within the member communities. These are issues (besides further process drivers and performance indicators) to be addressed in gaining a fuller understanding of the propensity for adoption of e-Marketplaces in the airline industry and would be worthwhile being included in future research projects.

\section{REFERENCES}

Airline Business, Special Report, "Information Technology - IT Trends Survey”, Airline Business, Aug, 2000, 55- 64.

Airlines Gate, Airline Industry, 2001, http://airlinesgate.free.fr/industry.htm.

Amit, R, Zott, C., "Value creation in e-Business", Strategic Management Journal, 22, 2001, 493-520. 
Agusdinata, B., de Klein, W., “The dynamics of airline alliances”, Journal of Air Transport Management, 8, 4, 2002, 201-211.

Button, K.J., 1996, “Liberalising European aviation: is there an empty core problem?”, Journal of Transport Economics and Policy, 30, pp. 275-291.

AT Kearney, Surviving the rebound - European aviation MRO finds a new path, Executive Agenda, 6, 4, 2004, 63-71.

Bagchi, S. and Watson, T.J., "Creating a Successful Business-to-Business e-Marketplace”, IBM Global Services, Somers, NY, 2002.

Bakos, Y., "The emerging role of electronic marketplaces on the Internet", Communications of the ACM, 41, 8, 1998, 35-42.

Barney, J.B., Fuerst, W.L., Mata, F.J., “Information technology and sustained competitive advantage: a resource-based analysis”, MIS Quarterly, 19, 4, 1995, 487-505.

Barratt, M., Rosdahl, K., “Exploring business-to-business marketsites”, European Journal of Purchasing \& Supply Management, 8, 2001, 111-122.

Baron, J.P., Shaw, M.J., Bailey Jr., A.D., "Web-based E-catalog systems in B2B procurement”, Communications of the ACM, 43, 5, 2000, 93-106. 
Büchel, B., Raub, S., "Building Knowledge-creating Value Networks”, European Management Journal, 20, 6, 2002, 587-596.

Burgeois, L., Eisenhardt, K., “Strategic decision processes in high velocity environments: four cases in the microcomputer industry”, Management Science, 34, 1988, 816-835.

Caves, D., Christensen, L. and Tretheway, M., “Economics of Density vs. economies of scale: Why trunk and local service airlines costs differ”, Rand Journal of Transport Economics, 1984, 471-489.

Chan, D., “The development of the airline industry from 1978-1998: A strategic global overview”, Journal of Management Development, 19, 6, 2000, 489-514.

Christiaanse, E., Markus, M.L., “B2B electronic marketplaces and the structure of channel relationships”, This is a paper presented at a conference, in ICIS Barcelona, 2003.

Christiaanse, E., Kumar, K., "ICT Enabled Co-ordination of Dynamic Supply Webs," International Journal of Physical Distribution and Logistics Management, 30, 2000, 268285.

Clarke, M.D., “Irregular airline operations: review of the state-of-the-practice in airline operations control centres”, Journal of Air Transport Management, 4, 2, 1998, 67-76. 
Clemons, E.K., 1986, "Information Systems for sustainable competitive advantage", Information \& Management, 11, 3, pp. 131-136.

Cool, K.O., Schendel, D.E., "Performance Differences between strategic group members“, Strategic Management Journal, 9, 1988, 207-233.

Crane, J.B., “The economics of air transportation”, Harvard Business Review, 22, 1944.

Duliba, K., Kauffman, R.J., and Lucas, H.C., Jr., “Appropriation of Value from Airline Computer Reservation Systems," Organization Science, 12, 6, 2001, 702-728.

Ehmer, H., 2001, "Liberalization in German air transport — analysis and competition policy recommendations: Summary of a German study”, Journal of Air Transport Management, 7, 1, pp. 51-55.

Flight International, World Airlines Directory, 2004.

Glisson, L.M., Cunningham, W.A., Harris, J.R., Lorenzo-Aiss, J.D., “Airline industry strategic alliances: marketing and policy implications”, International Journal of Physical Distribution and Logistics, 26, 3, 1996, 26-34. 
Gill, M.A., Wu, Z., "E-Markets: failed business model or barriers to diffusion of innovation?”, in Proceedings of the Seventh Americas Conference on Information Systems, Boston, August 2001.

Gulati, R., Nohria, N., Zaheer, A., "Strategic networks”, Strategic Management Journal, Special Issue, 21, 3, 2000, 203-215.

Hadaya, P., "Determinants of the Future Level of Use of Electronic Marketplaces among Canadian Firms", Proceedings of the 37th Hawaii International Conference on System Sciences, 2004.

Janic , M., "Liberalisation of European aviation: analysis and modelling of the airline behaviour”, Journal of Air Transport Management, 3, 4, 1997, 167-180.

Jarach, D., "The digitalisation of market relationships in the airline business: the impact and prospects of e-business”, Journal of Air Transport Management, 8, 2, 2002, 115-120.

Jarillo, J. C., "On Strategic Networks." Strategic Management Journal, 9, 1988, 31-42.

Joo, Y.B., Kim, Y.G., “Determinants of corporate adoption of e-Marketplace: an innovation theory perspective”, Journal of Purchasing and Supply Management, 10, 2004, 89-101. 
Kalakota, R.,Whinston, A.B., Electronic Commerce: A Manager's Guide, Addison-Wesley Longman, Inc., Reading, MA, 1997.

Kimberly, J.R., Evanisko, M.J., “ Organizational innovation: the influence of individual, organizational, and contextual factors on hospital adoption of technological and administrative innovations" , Academy of Management Journal, $24,4,1981,689-713$.

Kumar, R., Crook, C., “A multi-disciplinary framework of the management of interorganisational systems”, Database for Advances in Information Systems, 30, 1, 1999, 22-37.

Lee, H.G., Cho, D.H., Lee, S.C., "Impact of e-Business initiatives on firm value”, Electronic Commerce Research and Applications, 1, 1, 2002, 41-56.

Lehman J.A., "Organizational Size and Information System Sophistication", Journal of Management Information Systems, 2, 3, 1985, 78-86.

Lenz, M., Zimmermann, H.D., Heitmann, M., "Strategic partnerships and competitiveness of Business-to-Business E-Marketplaces: Preliminary evidence from Europe”, Electronic Markets, 12, 2, 2002, 100-111. 
Lijesen, M.G., Nijkamp, P., Rietveld, P., "Measuring competition in civil aviation”, Journal of Air Transport Management, 8, 3, 2002, 189-197.

Middleton, C., 2004, ITM700 Course Information: Fall 2004, School of Information Technology Management, Ryerson University, Toronto, Canada, URL: www.ryerson.ca/ cmiddlet/700/overheads/700week6.ppt

Miles, R. E., Snow, C.C.., "Fit. Failure and The Hall of Fame." California Management Review, 26, 1984, 10-28.

Nijkamp, P., Pels, E., 2002, “Developments in air transport economics: introduction”, Journal of Air Transport Management, 8, 3, pp. 137-139.

Oesterle, H., Fleisch, R., Business networking: shaping enterprise relationships on the Internet, Springer Verlag, Berlin, Germany, 1999.

Oum, T.H., Park, J.H., Zhang, A., Globalisation and strategic alliances: the case of the airline industry, Pergamon Press, Oxford, 2000.

Oum, T.H., Yu, C., Zhang, A., “Global airline alliances: international regulatory issues”, Journal of Air Transport Management, 7, 1, 2001, 57-62. 
Oum, T.H., de Wit, J., Yoshida, Y., "Developments in the deregulated air transport market”, Journal of Air Transport Management, 7, 5, 2001, 263.

Palvia, S. C., Chervany, N. L., "An Experimental Investigation of Factors Influencing Predicted Success in DSS Implementation," Information and Management, 29, 1, 1995, 4354.

Pemberton, J,D., Stonehouse, G.H., Barber, C.E., “Competing with CRS-generated information in the airline industry”, The Journal of Strategic Information Systems, 10, 1, 2001, 59-76.

Raisch, W.D., The E-Marketplace: Strategies for Success in B2B eCommerce, McGraw Hill, New York, NY, 2001.

Rasheed, H.S., Geiger, S., "Performance implications of internet-based information technology in value chain management“,2003, http://www.coba.usf.edu/departments/management/faculty/rasheed/tasktechnology.pdf.

Reimer, K., 1996, “The non-market preconditions of electronic markets: implications for their evolution and applicability”, European Journal of Information Systems, 5, pp. 75-83

Roy, J., Filiatrault, P., "The impact of new business practices and information technologies on business air travel demand”, Journal of Air Transport Management, 4, 2, 1998, 77-86. 
Sahi, B., “The airline IT trends survey 2004”, Airline Business, The Airline Industry Guide 2004/05.

Schneiderbauer, D., Fainsilber, O., “Low cost airlines gaining momentum in Europe“, Mercer Management Consulting, 2002, URL:

http://www.mercermc.com/Perspectives/Specialty/MOT_pdfs/Lowcostairlines.pdf.

Suen, W.W., “Alliance strategy and the fall of Swissair”, Journal of Air Transport Management, 8, 5, 2002, 355-363.

National Electronic Commerce Coordinating Council, “E-Procurement: Failure to implement, not an option!”, 2002, URL:

http://www.ec3.org/Downloads/2002/eProcurement.pdf.

Timmers, P., 1999, Electronic Commerce-Strategies and Models for Business-to-Business Trading, John Wiley \& Sons, Ltd.

Turban, E., Lee, J., King, D., Chung, H.M., Electronic commerce: A Managerial

Perspective, Prentice-Hall Inc., Englewood Cliffs, NJ, 2000.

Van Tulder, R., Mol, M., "Reverse Auctions or Auctions Reversed: First Experiments by Philips”, European Management Journal, 20, 5, 2002, 447-456. 
Vo., H., "The airline industry: a pro perspective”, Industrial Economics and public policy, 2002, 693.

White, L.J., "Economies of scale and the question of natural monopolies in the airline industry”, Journal of Air Law and Commerce, 44, 1979, 545-573.

Weller, T.C., "B2B eCommerce: The Rise of eMarketplaces”, Research Report, Legg Mason Wood Walker, Inc., Reston, VA, 2000.

Williamson, O.E., “Organisational innovation: the transaction cost approach”. In Entrepreneurship, Ronen, J. (ed), Lexington Books, Lexington (MA), 1983, 101-133.

Xu, K. \& Windle, "Re-evaluating returns to scale in transport”, Journal of Transport economics and policy, 28, 1994, 275-287.

Figure 1: Airline Industry Value Chain 


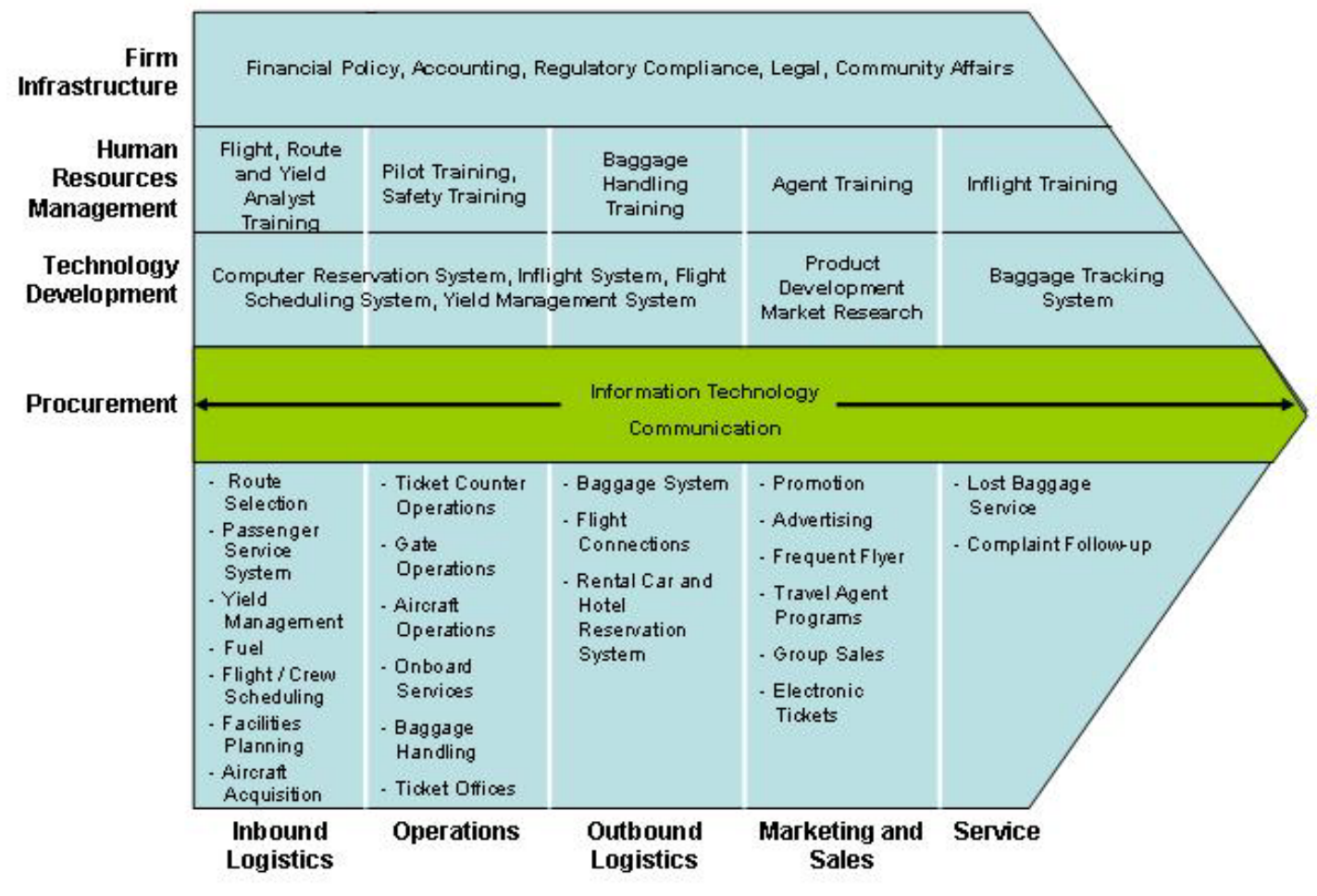

Modified from Middleton (2004)

Figure 2: Contingency Model 


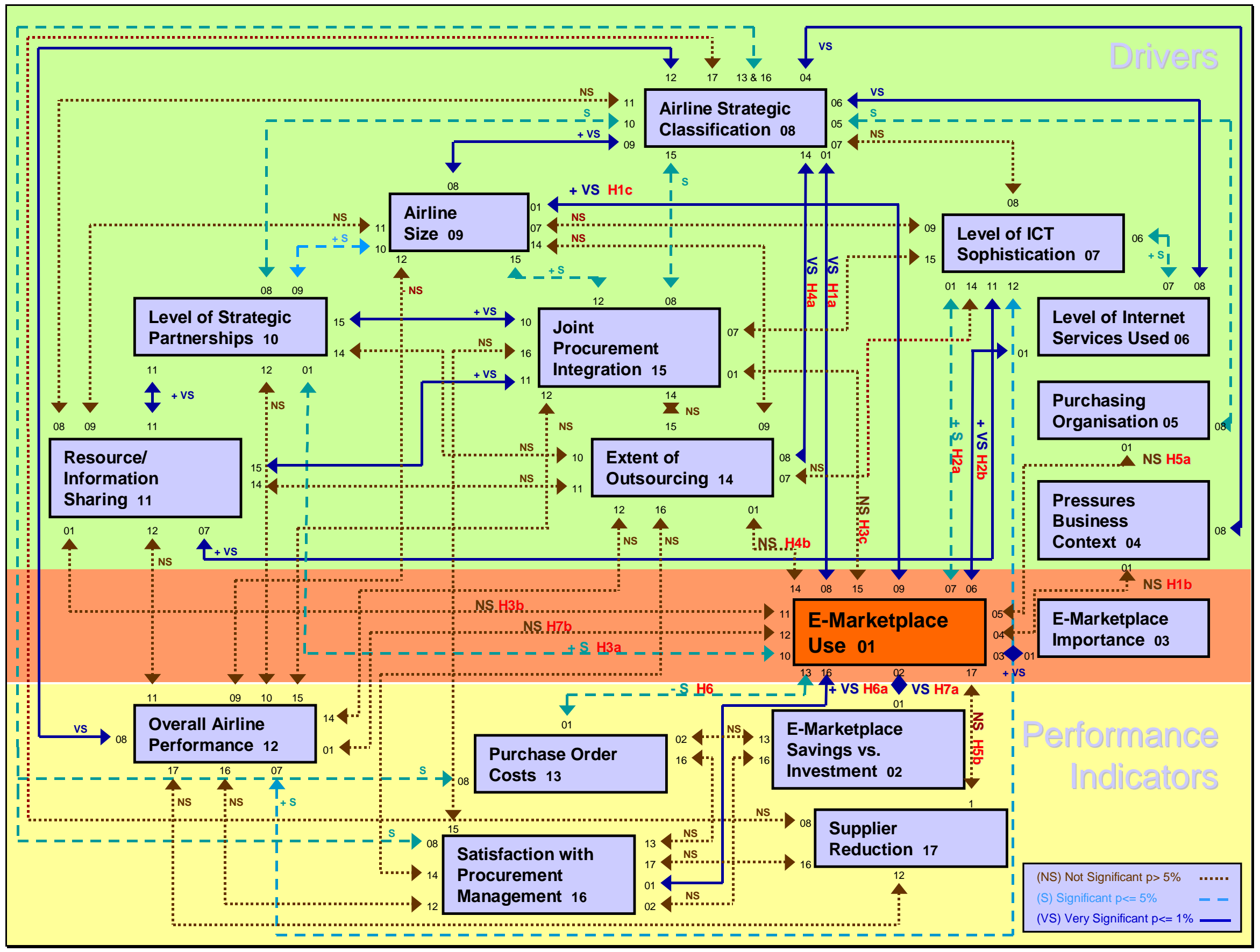



Figure 3: Performance Indicators by Airline Spend Categories

\begin{tabular}{|l|c|c|c|c|c|c|}
\hline $\begin{array}{l}\text { Mean Values I } \\
\text { Spend Categories }\end{array}$ & $\begin{array}{l}\text { Reduction of } \\
\text { Search Costs }\end{array}$ & $\begin{array}{l}\text { Time Efficiency } \\
\text { Enhancement }\end{array}$ & $\begin{array}{l}\text { Order Process } \\
\text { Facilitation }\end{array}$ & $\begin{array}{l}\text { Inventory Level } \\
\text { Reduction }\end{array}$ & & \\
Transparency & $\begin{array}{l}\text { Reduction of } \\
\text { Product Prices }\end{array}$ \\
\hline Powerplants & 3.15 & 2.92 & 2.71 & 2.22 & 2.63 & 2.84 \\
\hline Spares and Repairs & 4.11 & 4.04 & 3.73 & 3.74 & 3.70 & 3.99 \\
\hline Maintenance & 3.15 & 2.95 & 2.88 & 2.31 & 2.95 & 3.08 \\
\hline Fuel & 2.88 & 2.65 & 3.02 & 1.83 & 2.73 & 3.14 \\
\hline Interiors & 3.46 & 3.45 & 3.52 & 3.08 & 3.38 & 3.46 \\
\hline Catering & 3.16 & 3.06 & 3.11 & 2.54 & 3.03 & 3.42 \\
\hline Tools/GSE & 3.92 & 3.82 & 3.62 & 3.42 & 3.61 & 3.81 \\
\hline Office Supplies & 3.97 & 3.94 & 3.90 & 3.67 & 3.83 & 4.23 \\
\hline TOTAL & 3.48 & 3.35 & 3.31 & 2.86 & 3.24 & 3.50 \\
\hline
\end{tabular}

